\title{
Beyond the mutual constitution of states and markets: On the governance of alienation
}

\section{Jack Copley}

Department of Politics, Languages and International Studies

University of Bath, UK

Email: jc3275@bath.ac.uk

\author{
Alexis Moraitis \\ Department of Politics \\ University of York, UK \\ Email: alexis.moraitis@york.ac.uk
}




\title{
Beyond the mutual constitution of states and markets: On the governance of alienation
}

\begin{abstract}
International Political Economy (IPE) textbooks tend to present the concept of a clear state-market dichotomy as the disciplinary mainstream. Yet we argue that a critical consensus has emerged around the mutual constitution of states and markets. Underpinning this is the Polanyian thesis that economic activities are always politically embedded. However, we claim that this notion of state-market mutual constitution is inadequate to grasp the peculiarities of the capitalist political economy. While capitalist market relations are underpinned by states, they take on an autonomous, dominating logic that limits states' agency. Concretely, by reproducing international monetary relations, states accidentally contribute to the establishment of world labour productivity averages that force them to boost national competitiveness in order to keep pace with world market standards. In place of the notion of mutual constitution, then, we offer Marx's concept of alienation as a theory of a form of social relations that have escaped the control of the institutions that produce them. The challenge of state governance - reflected in the canon of liberal thought - is to reconcile the impersonal imperatives of world market relations with the creation of a legitimate national political project, which we term the politics of governing alienation.
\end{abstract}

Keywords: States and markets; globalisation; money; neoliberalism; Keynesianism; Polanyi; Marx.

\section{Introduction}

Ravenhill's popular textbook defines the 'central focus' of International Political Economy (IPE) as 'the interrelationship between public and private power in the allocation of scarce resources' (Ravenhill, 2017, p.21). While the emphasis on scarcity is not universally shared, it is widely accepted that the relationship between the public and private spheres is the stuff of IPE. As Watson (2005, p.21) writes, 'most contributions to the IPE literature have been couched in terms of the causal relationship between one entity called "states" and another one called 
"markets",. While only the most traditional approaches frame states and markets as embroiled in a 'tug of war wherein more market equals less state' - as early interventions in IPE's 'globalisation debate' argued - it is still supposedly commonplace to conceptualise the public and private as strictly separate realms (Clift, 2014, p.168). Indeed, as Bruff (2011, p.84) argues, 'it is not just the more mainstream contributions that deploy a state/market dichotomy, but also self-professed critical perspectives'. According to this widespread self-understanding, IPE is still fundamentally defined by a dualistic approach to states and markets.

We contend that this characterisation is outdated. Within IPE, there is growing agreement that 'market systems and political systems are co-constitutive' (Broome, 2014, p. 12). While the notion of a strict state-market divide is often held up as the IPE mainstream, against which theories of political/economic co-constitutiveness are presented as a radical counter-current, we argue that a kind of critical consensus has emerged around the concept of the mutual constitution of states and markets. This approach encompasses a diverse array of IPE interventions - including feminist and post/decolonial traditions, which have drawn attention to how market phenomena are enmeshed within gendered and racialised political structures (Bakker and Silvey, 2008; Elias and Roberts, 2018; Tilley and Shilliam, 2018). The mutual constitution thesis highlight the state's role in underpinning market developments by demonstrating the entwinement of markets in domestic institutional, ideational, and politicolegal structures. Within this literature, many key interventions draw specifically from Polanyi's concept of embeddedness (Cohen, 2008, p.116). As Block and Somers (2014, p.37) write, Polanyi's innovation was to insist that markets 'are neither natural nor autonomous, but they are deeply embedded within the state's exercise of power and authority'. States do not intervene at the expense of markets, but rather markets only exist because states produce and regulate them. While this is certainly true, within contemporary IPE this insight is 'all too often ... taken as the conclusion rather than the beginning of analysis' (Burnham, 2011, p.478). The claim that political and economic authority jointly constitute all human social reality risks slipping into banality if it is not further developed into a theory of capitalism's historically unique dynamics.

This article insists that IPE's mutual constitution approach fails to grasp how the capitalist market both depends entirely upon states and yet simultaneously constitutes an automatic social logic that imposes itself back upon states. Drawing from the 'value form' reading of Marx's work (see Pitts, 2019), we propose that Marx's concept of alienation is better suited to grasp this double reality. By forging and reproducing capitalist money relations domestically and through international monetary systems, states accidentally produce a global dynamic of economic competition over labour time that subordinates them to its dictates. 
Money is the central nervous system that transmits changes in labour productivity in one part of society to the other, promising economic ruination for firms if this new standard cannot be matched (Rubin, 1973). While the construction and maintenance of this monetary system are 'matters of state', such market-making unleashes an autonomous logic of its own (Bonefeld, 2014, p.182). Alienation, then, denotes not just a feeling of estrangement, but the actual loss of control by political institutions over the social relations that they create (Postone, 1993, p.159). The challenge that states face in managing this system of perpetual competition, we argue, can be understood as the contradictory politics of governing alienation: states must navigate a path between disciplining domestic social relations in line with global market averages, so as to maintain the national economy's viability, and postponing these competitive pressures to ensure domestic social stability. The mutual constitution approach fails to capture the runaway dynamic of capitalist development, whereby states unconsciously produce an alienated logic that escapes their control. Further, its one-sided emphasis on the market-making function of states misses the contradictory nature of the governance of alienation.

We begin by discussing the different varieties of the IPE mutual constitution thesis. During the 'globalisation debate', certain scholars insisted that economic globalisation did not entail the state's retreat, but rather a transformation and even expansion of state activities. Central to many of these accounts was the Polanyian-inspired notion that market activity is always embedded in political institutions and ideational norms. Next, we examine the shortcomings of the mutual constitution approach. While the latter tends to posit market embeddedness and disembeddedness as mutually exclusive conditions, we argue that capitalist markets are simultaneously rooted in political, social, and cultural institutions and characterised by an automatic logic. This article then explores the politics of the state's governance of this alienated social dynamic. We claim that both neoliberal and Keynesian strands of liberal thought are useful, though partial, lenses for understanding how states are forced to enact both economic discipline and palliative measures in order to manage the contradictory forces of world market competition and national legitimacy concerns.

\section{Varieties of mutual constitution}

The notion that states and markets together constitute an interwoven social whole is older than the field of IPE itself. Nevertheless, within the disciplinary boundaries of IPE proper, the most sustained discussion of state-market mutual constitution emerged from the 'globalisation 
debate'. This debate was concerned with the globalisation of economic relations following the demise of the Bretton Woods system, and the implications for states' capacities to govern (Mittelman, 2000; Cameron and Palan, 2004; Phillips, 2005). The first salvo of this debate was fired by 'globalist' accounts, which insisted on the contemporary state's 'retreat' (Strange, 1996) or 'withering away' (Held, 1995) in the face of unrestricted global capital flows. Such accounts were underpinned by an understanding of states and markets as engaged in a zero-sum power struggle (Sørensen, 2004). One important response to this dichotomous understanding of states and markets was the 'competition state' approach (Cerny, 1997; Jessop, 2003; Hirsch, 1997). This approach argued that, confronted by economic globalisation, states do not retreat, but increasingly 'internalise' the market's competitive logic, prioritising the national economy's 'enterprise, innovation and profitability' over the provision of domestic social solidarity (Cerny, 1997, p.260). By arguing that through the process of globalisation 'the frontiers between state and market become blurred', the competition state approach pointed towards the co-constitution of political and economic activity (Cerny, ibid, p.267). Yet a more thorough mutual constitution approach would emerge later in the globalisation debate from IPE scholars drawing from the concept of embeddedness first proposed by Polanyi.

The mutual constitution thesis, we argue, is emblematic of the 'Polanyian turn' in IPE, which has endeavoured to unveil the interventionist state powers that underpin the neoliberal market (Knafo, 2020). Directly or indirectly, the mutual constitution thesis is inspired by the notion of embeddedness, as it seeks to highlight the interpenetration of political, institutional, and economic processes. Polanyi's concept of embeddedness has been the subject of various interpretations, from Granovetter's (1985) emphasis on the embeddedness of agents' economic behaviour in networks of social relations, to Block's (2003) holistic view of the 'always embedded economy', which contends that no economic system can ever be detached from its cultural and social context. IPE mutual constitution accounts draw inspiration from Polanyi and the concept of embeddedness in order to counter the globalist approach's rigid state-market dichotomy by instead affirming their interwoven relation (Amoore, 2002, p.49; Cohen, 2008, p.116; Holmes, 2018, p.21).

Within the globalisation debate, the field of Comparative Political Economy (CPE) disputed the institutional convergence in the face of globalisation assumed by existing accounts and instead laid emphasis on the national variations in states' adaptations to economic change (Crouch and Streeck, 1997; Hollingsworth and Boyer, 1997; Hall and Sosckice, 2001; Campbell, 2004; Amable, 2003). CPE espouses the basic tenet of the Varieties of Capitalism (VoC) school, namely that globalisation leads to differentiated adaptations, rather than 
homogenisation, as national political economies respond to external developments by building upon the peculiar characteristics of their domestic institutional set-up of market relations (Hall and Sosckice, 2001; Hancké, 2009, p.4). Whether in its Granovetterian or Polanyian guise, CPE is influenced by the concept of embeddedness (Clift, 2014, p.209; Jackson and Deeg, 2008 p.683; Peck and Theodore, 2007, p.751). More precisely, the comparative tradition is premised upon a notion of 'institutional embeddedness', whereby market agents always operate within a given social and institutional context which ultimately conditions their economic strategies (Weiss, 2010, p.183). Despite the international economic challenges common to all states, CPE shows that states' adaptation to liberalisation pressures cannot be extricated from the institutionally mediated compromises and political negotiations within the domestic social order (Amable, 2003, 2017, pp.3-9; Hancké et al., 2007, pp.19-23; Hall and Thelen, 2009).

While CPE approaches do not equally focus on state-market relations - the state's role being conspicuously absent in VoC accounts (Clift, 2014, p.201) - their portrayal of globalisation as a source of cross-national diversity suggests that economic change is always 'institutionally conditioned' (Hall, 2007, p.76), rather than imposed by global markets in a disciplinary manner. Other CPE scholars are keener to emphasise the state's role in giving birth to different national breeds of capitalism (Levy et al, 2006; Molina and Rhodes, 2007; Jackson and Deeg, 2008, pp.699-700; Schmidt, 2009). In this vein, as domestic political traditions and patterns of state action are imprinted on nations' diverse trajectories of economic adjustment, the state is revealed to do far more than mechanistically internalise external market imperatives (Vail, 2018). In fact, the comparative approach highlights that states have a 'market-making and market-shaping' capacity that varies nationally, pointing to the intertwined relationship between states and markets (Clift and Woll, 2012, p.310).

Constructivist approaches concur in viewing states and global markets as 'mutually constitutive' (Geske, 2000). Their co-constitutiveness is emphasised through the role of ideational factors in shaping economic trajectories (Blyth, 2013; Seabrooke, 2007; Cameron and Palan, 2004). Indeed, markets are not autonomous, insofar as they are endowed with meaning and purpose by political agents (Abdelal, 2009). Often building on Polanyi's critique of laissez-faire, such approaches highlight that the separation of market and state relies on an (neoliberal) ideational 'fiction' (Maucourant and Plociniczak, 2013; Peck, 2010). As such, different market-making practices, from neoliberal to social-democratic, can be viewed through the concept of 'ideational embeddedness', which denotes the way that ideological paradigms 'shape, structure, and change market regimes' (Somers and Block, 2005, p.260). 
Ideational embeddedness chimes well with the insights of so-called third wave globalisation theory (see Bruff, 2005; Berry, 2011). For this school it is political agents' interpretation of globalisation, not globalisation itself, that leads to specific policy outcomes, such as trade/financial liberalisation (Lister and Marsh, 2006). For instance, policy-makers may appeal to subjective understandings of globalisation as a structural constraint in order to implement contingent neoliberal policy preferences (Hay and Rosamond, 2002; Watson and Hay, 2003). It is policy-makers' 'cognitive perceptions' of conjectural economic phenomena that frame institutional responses to market developments, as opposed to global market forces (Blyth, 2001, 2002; Abdelal, Blyth, and Parson, 2009; Campbell, 2004). From this standpoint, state-market relations are 'discursively' constructed - it is not out-of-control markets that predetermine state policy but '[t] he believed-in myth of disembedded markets' (Caporaso and Tarrow, 2009, p.596, our emphasis; see also Hay, 2002.

While certain comparative and constructivist mutual constitution accounts have made indirect overtures to Polanyian thought by adding an institutionalist or ideational twist to the concept of embeddedness, the mutual constitution thesis has found its most radical defenders in approaches that directly draw from a Polanyian notion of embeddedness. Such approaches follow Polanyi's proposition that the economy, market or otherwise, is always 'enmeshed in institutions, economic and noneconomic' (Polanyi, 1957, p.250; see Gemici, 2008). As opposed to an autonomous sphere, the market is seen as an organic part of a wider social whole (Block and Somers, 1984; Block, 2001, p.xxiii). The market's functioning is not reducible to the economic transactions between atomised, rational individuals, but is inevitably entangled in a larger web of non-economic relations and reflects the legal, cultural, and political arrangements of a given society (Barber, 1995; Krippner, 2001).

The neo-Polanyian understanding of the economy as 'always embedded' (Block, 2003; Barber, 1995) radically departs from the analytical dichotomisation of the political and economic into distinct spheres of social organisation and instead highlights the 'mutual constitution of state and economy' (Block and Evans, 2005, p.506; Krippner and Alvarez, 2007, p.233). Instead of disciplining states, markets are dependent upon constant state intervention to regulate labour, land, and money - the 'fictitious commodities' that, absent political regulation, would not be traded on markets (Block, 2003, p.282). As Polanyian thought reveals, the state is tasked with a 'market-making' role (Levy, 2006, p.44), since markets are 'ultimately created and sustained through the mechanisms of the state' (Underhill and Zhang, 2005, p.8). Underhill's concept of the 'state market condominium' captures well the embedded view of the global economy, as global governance is interpreted not as belonging exclusively to the market 
or state sphere, but as constituting an organic whole formed by the mutually exerted influence of both political and economic agents (Underhill, 2000).

Thus, from a neo-Polanyian perspective, the era of neoliberal globalisation has not heralded the transition from a system of market embeddedness to a generalised retrenchment of the state's interventionist powers. Neoliberalism simply represents a different articulation of embeddedness (Cahill, 2014; Vogel, 2018, p.133). The neoliberal economy remains embedded in a historically specific constellation of ideological paradigms, institutional arrangements, and balances of class forces (Cahill, 2018). Concretely, the deregulation of financial and labour markets does not signal state retreat, but the emergence of a qualitatively altered form of political management of these spheres (Krippner, 2007; Block, 2007). Fundamentally, for neoPolanyian IPE, no project of installing a self-regulating market, such as neoliberalism, can ever prove successful. Drawing from Polanyi's notion of the double movement, it is suggested that the countermovement, or society's resistance to the market's dislocating effects, poses obstacles to full economic liberalisation and forces the state to deploy regulatory means that guarantee 'some threshold level of embeddedness' (Block and Somers, 2014, p.93; see also Porter and Craig, 2004; Sandbrook, 2014).

While neo-Polanyian IPE goes to great lengths to demonstrate the fully embedded character of markets, an alternative, critical reading of Polanyi's work contests the applicability of 'embeddedness' to capitalism. Lacher (2019) shows that the concept of the 'always embedded economy' obscures the central novelty of Polanyi's thought, which sought to demonstrate that the market's self-regulating logic was incompatible with attempts to embed the economy by placing it under social control. This 'hard' reading of Polanyi contrasts with the 'soft' interpretation of neo-Polanyian IPE (see Dale, 2016; Goodwin, 2018), as it draws attention to the market's disembedding tendencies: while in pre-capitalist societies economic activity was fixed within existing social conventions, the capitalist market is characterised by an historically novel organising principle, whereby different social activities are subordinated to the market's autonomised logic (Cangiani, 2017). This interpretation crucially distinguishes between the instituted and embedded character of economies. While the former suggests that every society institutionalises, in different ways, its production and distribution, the latter essentially refers to the blending of the economic with other social spheres (Harvey, 2007, p.165; Machado, 2011, p.136). Disembeddedness connotes that society is effectively subordinated to the market's price mechanism, as the worth of goods, land, and incomes is automatically dictated by fluctuations in supply and demand, rather than directly administered by social actors (Machado, 2011). Although socially instituted, the capitalist market escapes 
the conscious control of its creators and imposes its own rationality upon society, according to this reading. As Dale (2010, p.202) puts it, "that the liberal market is "embedded" in the sense of "instituted"... does not negate its "disembeddedness" at other levels'.

The critique of the soft Polanyi can be levelled to the mutual constitution thesis as a whole. The varieties of mutual constitution discussed here - the 'institutionally conditioned' economy, the ideational construction of market regimes, and the 'always embedded market' suggest that states are internally related to markets and actively integrate their economies into the global scale in varying, politically embedded ways. However, if the full implications of the state's market-making role are considered, then it could be argued that although market activity is undergirded by state authority, the motion of the market may escape political control and inadvertently tie the state's hands. As we contend, the mutual constitution of states and markets begets their mutual subordination to the disciplinary logic of capitalist competition.

\section{From mutual constitution to alienation}

The IPE literature on state-market relations presents a binary of possibilities: either the market becomes disembedded and escapes its anchoring in social relations, as early globalist accounts suggested, or the market is embedded in a matrix of socio-political relations and thus politics predominates, as the mutual constitution thesis argues. However, as alluded to above, the hard reading of Polanyi suggests that market society's historical novelty lies in its double-sidedness, as the economy is both socially engineered and constitutes a disembedded force that dominates all other social spheres.

In this section, we argue that this double reality, unique to capitalism, is best captured by Marx's writings on alienation. Although Block (2003) emphatically stresses the incompatibility of Marx's theory and the 'always embedded' account of state-economy relations, others have noted the similarities between the hard interpretation of Polanyi and Marx's account of capitalism as an economic system that, although socially constituted, subjects socio-cultural institutions to its own logic of reproduction (Cangiani 2011, p.198; Dale 2011, p.333). More precisely, the concept of alienation transcends the embedded/disembedded dichotomy by expressing how people collectively produce an economic system that in turn disciplines them. Markets depend for their functioning upon cultural norms, forms of knowledge, and performative acts. Further, states undergird every moment in the circuit of capital, forging the legal framework for market transactions, policing the cultural forms that 
support the market's operation, and governing money. Yet capitalism also escapes the control of the participants that give it life and imposes itself back upon them as an impersonal force. In making this argument, we draw from the value-form Marxist tradition that scrutinises the historically-specific social forms that constitute capitalist society - particularly monetary exchange as the form of capitalist socialisation - and the manner in which these forms acquire a self-reproducing logic that dominates the lives of the very individuals that create them (Pitts, 2019; Bonefeld, 2014; Postone, 1993). Applied to the study of state-market relations, the valueform interpretation of alienation suggests that it is the role of money in mediating the social productivity of labour that explains how the market both depends upon state interventionism and exerts a disciplining force over economic policy.

\section{Money and alienation in the global market}

The role of alienation in Marx's theoretical system has been a source of controversy since the 1932 publication of his Paris Manuscripts (Musto, 2010, p.82). Here, Marx argued that workers' alienation in capitalism had four aspects: alienation from the product of their labour, the labour process itself, their fellow human beings, and their very 'species-being' (Marx, 1992). This argument has been interpreted in various ways. A common reading states that alienation must be understood as an experiential category: as a violence wrought upon workers' subjectivities under capitalism (see Fromm, 2013). For Althusser (2005), such subjectivism was a characteristic of Marx's early 'humanist' writings that preceded his later 'scientific' work (i.e. Capital). Yet this notion was roundly critiqued by scholars such as Mészáros (1970) and Ollman (1971), who argued that alienation remained a central principle of Marx's mature critique of political economy. For Mészáros, alienation under capitalism is closely tied to the institution of private property, which transforms humans' metabolic interaction with nature into a tool of class oppression; while for Ollman, alienation results from the division of labour, which reaches its most advanced stage in capitalist society (Clarke, 1991, p.69-71).

However, for several authors within the value-form tradition, Marx neither abandons alienation in his later writings nor uses it in the same way throughout his work. Instead, as Heinrich (2016, p.96) writes, Marx develops alienation from a theory of individual dehumanisation to a general theory of 'the inability of humans to control the social relations they produce' (see also Rubin, 1973). According to this reading, which this article adopts, people do not simply feel alienated because the products of their labour are appropriated by 
capitalists nor because of the monotony of divided labour. They are alienated because their social universe is regulated by an automatic social mechanism that they have accidentally created but cannot reign in (Postone, 1993, p.159). As Smith (1993, p.126) explains, 'the whole of Capital can be read as an extended analysis of a phenomenon of "objective alienation"', that is, 'the alienation of human beings from a condition of mastery over their affairs'. The root cause of this historically unique form of collective alienation can be found in the capitalist mode of human socialisation, namely money-mediated commodity exchange.

Money has existed since antiquity, performing a variety of economic as well as ceremonial, religious, and political functions (Davies, 2002). Indeed, the Roman Empire boasted an advanced monetary system, with currency circulating within its 'vast domains' and 'beyond the imperial boundaries' for the purposes of facilitating trade, extracting tributes, and paying armies (ibid, p.90). Yet this monetary complexity 'constituted a thin veneer of sophistication' over what was a chiefly subsistence economy - the great majority of Roman labourers were peasants who produced directly for their own consumption (Hopkins, 1980, p.104). Money performs a very different role in capitalist society due to the universalisation of market dependence (Wood, 2002). In a system in which specialised private producers are formally independent of one another and the majority of the population are denied direct access to what they need to survive, money constitutes the 'connecting link' between atomised individuals and allows for the formation of a single 'unified system' (Rubin, 1973, pp.7-10).

Capitalist money can purchase any sort of product or service, regardless of its corporeal qualities, as long as it has a price tag. Qualitatively distinct kinds of labour are rendered equal in the eyes of money as, through its lens, every good is regarded as the product of 'undifferentiated human labour' (Marx, 1976, p.204). In other words, the products of different working activities are 'homogenised' and become distinguishable only by the price they obtain on the market (Saad-Filho, 2019, p.53). Money guarantees the exchangeability of commodities, by performing the role of a 'universally understood language' (Simmel, 2010, p.4), with prices being the 'money-names' it attributes to different saleable goods (Marx, 1976, p.195). Indeed, the 'impersonality and colourlessness' of money allows the objective commensuration of different products by establishing different quantitative relations of equivalence between them, expressed in prices (Simmel, 1991, p.19). By stripping goods of their physical qualities, money relations essentially represent the relationship between different quantities of labour time (Rubin, 1973, p.156).

However, it is not the labour time expended in individual workplaces that determines the value of different sectoral products, but the average time that companies within the whole 
market nexus expend for their production (Heinrich, 2012, p.51). What Marx termed 'socially necessary labour time' (1976, p.129) constitutes the 'external yardstick' that communicates the economic worth of individual products and coordinates an otherwise decentralised and privately conducted system of production (Marx, 1993, p.269). The different production methods and technologies deployed by existing firms to expand their market shares give rise to average productivity standards, which money translates into benchmark prices that must be matched to profitably compete within the market. By participating in commodity exchange, individual producers are submitted 'to the test of the market' (Clarke, 1991, p.107), as their solvency depends on their ability to abide by average productivity levels (McNally, 1993, p.179). Capitalist exchange thus generates a compelling market norm that escapes the control of participating agents and instead dominates them as a matter of market survival (Tombazos, 2013).

In a way, market competition concretises the adage that 'time is money' (Lotz, 2014, p.55). For individual companies, realising their products' full latent value hinges upon their capacity to produce 'within time' by bringing production costs below prevailing market prices (Bonefeld, 2010, p.269). The dynamism of this system owes to the mechanism of competition, as general increases in productivity are experienced by individual producers as an external constraint to which they must conform 'under penalty of ruin' (Marx, 1981, p.353). Although socially constituted, capitalist exchange ultimately gives rise to an abstract and 'temporal form of domination', as the viability of firms rests on their positioning in relation to the average productivity levels that they themselves contribute to (Postone, 2015, p.14). The historically specific form of socialisation under capitalism generates an economic logic that is alienated from the wider social whole.

The alienating features of capitalist exchange are further amplified by the fact that the market validation of firms' productivity operates on a global scale (Bonefeld, 2014). Indeed, the compelling productivity norms described by Marx are essentially a world market phenomenon, as the measure of value is not established nationally, 'but by the average necessary time of labour on the world market' (Marx, 2010, p.384, emphasis in original). Socially necessary labour time, in a sense, 'dictates the pace', as the commensuration of commodities on the world market gives rise to global productivity and price standards (Tomba, 2012, p.168). There is a distributive logic within the world market that operates quasiautomatically, as it allots low, average, or high profits to individual capitals depending on whether they fall behind, match, or supersede average productivity levels. 
This competitive mechanism gives rise to uneven rates of development between and within national geographical spaces (Smith, 2010), as advanced producers leading the race indirectly force less developed ones to catch-up and reach the productivity frontier they set (Barker, 2006). Take, for example, the 'premature deindustrialisation' experienced by low- and middle-income countries in the Global South (see Rodrik, 2016; Dasgupta and Singh, 2006). In the Global North, deindustrialisation, commonly defined as the declining share of industrial employment, resulted from the so-called 'economic maturation' of societies, whereby growing manufacturing productivity and the relative stagnation of demand for manufactures rendered a great share of industrial labour progressively redundant (see Rowthorn and Wells, 1987). Countries in the Global South, however, deindustrialise not because they have achieved the same industrial maturity. Their premature deindustrialisation is largely due to the massive productivity increases in global manufacturing and the consequent decline in prices achieved by advanced nations or late-industrialisers such as China, which now 'discourag[e] newcomers in developing countries from entry' (Rodrik, 2015, p.8). Thus, the interplay of decreasing production times and international competition raises the productivity frontier one must reach to be profitable on the world market.

In sum, money is both a socialising bond uniting private firms and consumers in the world market and an alienating social technology subjecting market agents to the tyranny of global productivity averages.

\section{Between market-making and impersonal domination}

Just as individual market actors contribute to the creation of productivity norms that inadvertently end up dominating them, so too individual states construct the conditions of global market competition over which, once established, they lose control to a great extent.

Within the domestic market, the competitive commensuration of different goods would be impossible without the state's authority to print and establish a 'mandatory currency benchmark' as the medium of exchange (Brunhoff, 2003, p.45). Concurrently, by interlocking their national currencies in the foreign exchange market, states jointly give rise to a system of global market commensuration, as exchange rates operate 'like the eye of a needle through which prices of all domestic goods and services are linked and compared with the prices of foreign output' (Cohen, 2015, p.62). Hence, it is states that spur the race over global productivity averages, as exchange rates enable the comparison of domestically operating 
firms' productivity relative to world market conditions (Kettell, 2004). At the same time, by entangling domestic currencies within the web of world monies, states subject themselves to the temporal dynamic of global competition (Clarke, 1988). For states, failure to match global productivity standards translates into various forms of crisis, such as financial downgrading, balance of payment deficits, capital flight, speculative attacks on currencies etc., which call for corrective measures to enhance domestic productivity (Bonefeld, 2000, p.38). Although the unfolding of global market dynamics relies on state authority, the market also constitutes the terrain of the state's own domination.

On the one hand, then, the state indeed has a market-making role, as suggested by the mutual constitution approach. In fact, the market's functioning relies on certain guarantees that it cannot, by itself, provide, such as a readily employable labour force or a trusted currency functioning as the official medium of circulation. As noted by Polanyi (2001), labour and money are 'fictitious commodities' whose existence as saleable artefacts owes to state-enforced institutional and legal arrangements (Cahill, 2014, p.71). This is further supported by Chartalist theories of money, according to which the latter is 'a creature of the state' (Lerner, 1947). For such accounts, money emerges not from the spontaneous need of market actors for a neutral exchange medium, but from states' enforcement of a standardised accounting unit to measure the debt/tax obligations of its subjects (see Knapp, 1924). The emergence of national currencies has historically been 'an intensely political process' that states initiated to both accommodate their own financial needs and to forge national markets (Helleiner, 2003, p.2). Thus, the (re)production of markets relies on states' political authority and, in this sense, markets can be understood as politically instituted.

On the other hand, however, the state's market-making role constitutes the source of its own alienation, as money is simultaneously state-crafted and state-disciplining. Although money and markets are state creations, they acquire dynamics that discipline state behaviour. In $17^{\text {th }}-18^{\text {th }}$ century Britain, modern state-finance relations were born out of the state's necessity to wage its imperial wars (Clapham, 1966). Indeed, the state-founded and privately-managed Bank of England assisted the state's war efforts in return for future interest repayments financed out of taxation, and in the process issued and re-traded notes representing state debt on secondary markets (McNally, 2014, pp.13-14). Although state-enacted, this process increasingly subjected public finances to international financial markets, as the viability of state debt rested on their verdict (McNally, 2014, p.25). The making of markets and money are fundamentally state-led exercises, but economic policy becomes, in turn, shaped, altered, and regimented by the state's own creations. Money-making is a 'limited power', as the state fails 
to control the full context in which money operates, such as the sentiment of financial markets, the strategic actions of other states, international capital flows etc. (Beggs, 2017, p.470). That the state creates money is not enough; it must subsequently 'act strategically in or upon the market situation' in order to defend its international value (Beggs, 2017, p.472). While an essential precondition for the functioning of markets, the state's management of money effectively reproduces the 'market-based constraints on policy-making' (Brunhoff, 1978, p.82).

The world market's disciplinary effects are not evenly exercised across the globe, as the Global South is more vulnerable to violent fluctuations in capital markets (Alami, 2018). In fact, the world economy is characterised by an uneven distribution of monetary power, leading to 'hierarchies in monetary relations' (Cohen, 2015). In the face of balance of payments disequilibria, countries at the top of the chain can rely on their access to global credit or their pool of foreign reserves to defend their currency's value and delay the costs of domestic adjustment (Cohen, 2015). Countries issuing the preeminent global reserve currency, such as the United States today, enjoy 'exorbitant privilege' in this sense (Eichengreen, 2011). These hierarchies constitute temporary pecking orders in a wider competitive system, in which power is exercised heteronomously and experienced unevenly across national economies. The monetary power of different countries describes the degree of manoeuvre that individual states have in responding to the impersonal force of global competition. While states might appear to loosen the pressures of competition, they 'certainly [do] not eliminate these constraints', but merely find a way to temporarily navigate them without immediate sanctions (Brunhoff, 1978, p.93).

The complicity of states in reproducing an alienated system of global competition bears crucial implications for IPE. Mutual constitution approaches have essentially strived to find a balance between the agential power of the state and the structural forces of the market. This endeavour has its limitations, as it remains unclear 'who or what actually exercises authority' (Cohen, 2007, p.117). The struggles encountered by IPE in answering this question stems from its traditional understanding of power 'as an entity that is held, plotted or wielded' by certain political or economic institutions, instead of a fundamentally more abstract phenomenon (Amoore, 2002, p.59). Thus, mutual constitution approaches fail to consider that power in the global economy may be located neither in the state nor the market realm, nor simply shared amongst them, but instead impersonally exercised on both state and market actors. Our valueinformed approach seeks not to find the correct balance between state and market authority, but to demonstrate that the mutual constitution of states and markets creates 'an alien social power' that mutually subordinates them to the temporal dynamic of capitalist competition (Marx, 1993, 
p.197, emphasis in original). By creating and reproducing markets, states submit themselves to the fugitive logic of capitalist exchange, which compels them to defend national productivity in the face of global averages for the sake of their own institutional survival.

\section{The politics of governing alienation}

This article has argued that IPE can better grasp capitalist dynamics by shifting from a framing of state-market interaction in terms of mutual constitution to exploring how states accidentally produce an alienated logic of competition that in turn dominates them. In this section, we argue that this conceptual move has significant implications for how IPE understands the nature of state governance of capitalist society, which we term the politics of governing alienation. We begin by exploring the contradictory nature of this form of governance in the context of Bretton Woods, before exploring how this governing dilemma has been articulated within liberal political economy and then finally discussing how states are simultaneously pulled in opposing directions by the forces of world competition and national legitimacy.

States in capitalist society are confronted by a dilemma. As Holloway (1995, p.124) argues, 'there is a basic territorial non-coincidence' between the global scale of capitalist social relations and the national boundaries of the state. Both territorial scales entail distinct, if interrelated, imperatives for the state. First, as discussed above, by plugging the national scale into the grid of world value relations through the convertibility of their currency, states contribute to an alienated system of endless competition. Particular governments must wield the state apparatus to successfully navigate these competitive pressures or face a range of impersonal sanctions. Second, governing legitimacy derives not just from the national economy's success in competing on the world stage, but also from the state's ostensible role as 'the embodiment of the general interest of society' (Clarke, 1988, p.128). If governments fail egregiously to marshal state institutions to meet people's demands, they face democratic sanctions at the ballot box or in the streets. The governance of alienation, we argue, signifies the need for states to reconcile their acquiescence to the alienated dictates of world competition with the construction of a legitimate national political project.

Yet such reconciliation is fleeting, and pregnant with its own disintegration. The continual necessity to compete over labour productivity does not gel well with long-term, stable political projects. It is perhaps useful to briefly discuss the 'embedded liberalism' of the Bretton Woods system of global governance, as it is often understood as a successful attempt to embed 
global competition within a political framework of mass democracy (Ruggie, 1982). This 'paradise lost' (Eichengreen, 1994, p.1) was achieved by eliminating trade barriers and imposing currency convertibility, while allowing governments to somewhat insulate their national political projects from global economic forces through exchange rate adjustments, restrictions on capital mobility, and the creation of the International Monetary Fund (IMF) to aid states facing foreign exchange shortages (Cohen, 1977, pp.91-2). However, Bretton Woods' actual operation reveals how many states faced an intensifying battle between the pressures of international competition - manifested in balance of payments deterioration, currency speculation, and shrinking reserves - and the demands of an enfranchised working class expressed through electoral defeats, strikes, or riots. As Eichengreen $(1994$, p.2) observed, once the pent-up growth potential from the Depression and the Second World War had been exhausted, and barriers to global capital flows began to erode, governments again became 'torn between the maintenance of external balance and financing objectives like Europe's welfare state and America's Vietnam War'.

In Britain, this contradiction took the form of the 'stop-go' pattern of development (Brittan, 1971). During the 'go' period, British governments would stimulate demand in order to raise employment and protect their political legitimacy. Yet without a concurrent increase in national economic competitiveness, increased demand would tend to raise imports, putting pressure on the current account and depleting reserves. This would provoke speculation against the pound and a currency crisis would ensue. Governments would thus be forced to bring about a 'stop': monetary and fiscal policy would be tightened, economic contraction would ensue, and the balance of payments and reserves would recover (Cairncross, 1995, p.14). The cycle would then begin anew. While Britain was perhaps unique in its lack of long-term planning, even French dirigisme constituted an uneasy compromise that quickly began to come apart at the seams. The dirigiste state utilised an array of policy instruments to coordinate its nationalised industries and domestic financial system so as to wed France's global economic performance with the mass politics of the Fifth Republic (Clift, 2017, p.517). Yet the failure to restrain domestic income growth gave rise to an inflation-prone economy that crippled national competitiveness, in turn necessitating frequent currency devaluations (Knapp and Wright, 2006, p.461). It became increasingly difficult to discipline labour in line with global productivity averages following the May 1968 upheavals. Torn between maintaining national competitiveness and social peace, French governments initiated a series of palliative measures, such as subsidies to failing sectors, which further eroded national competitiveness, bringing France to the precipice of economic unviability (Levy, 2008). 
The contradictory nature of the governance of alienation - that is, the tension between the need for the state to both respond to global competition and maintain a legitimate, governable social order - is a central concern of liberal political economy. Indeed, for Smith (2001, p.947), the capitalist division of labour increases the nation's opulence, yet it also engenders stark inequality that 'excites the indignation of the poor', which the state must temper through the creation of a legal and moral framework that socialises workers into commercial society. This trepidation is a continuous vein that runs through the liberal canon, yet the counterposed needs to adhere to world competitive dictates and assuage popular pressures are best articulated by two opposing poles of liberal thought: neo/ordoliberalism and Keynesianism.

Neo/ordoliberalism conveys particularly well the state's need to comply with the alienated pressures of global competition, and suggests a legal paradigm within which this could be achieved. For Hayek, the unconscious coordination of the market system - or 'catallaxy' can only operate within a state-policed legal framework: 'A catallaxy is thus the special kind of spontaneous order produced by the market through people acting within the rules of the law of property, tort and contract' (1982, p.109). For ordoliberals, the state must 'not allow itself to become the prey of the competing social interests', nor beholden to a 'mass democratic citizenry' (Bonefeld, 2016, p.3). Instead, a strong, impartial state is required to provide the legislative basis to protect the economy from monopolies or excess democracy, and enforce market outcomes. Practically, this suggests a 'rule-based (constitutional) framework' in which government's discretionary power is constrained through institutional safeguards (Feld, Köhler, and Nientiedt, 2015, p.2). Such safeguards should not simply be forged at the national level. Rather, neoliberals advocate a complex system of global governance, which Slobodian (2018) terms 'ordoglobalism', constituted by a multi-scalar layering of international treaties and supranational institutions that can fully 'encase' capitalism's wiring from democratic interference. Take, for example, the case of state aid rules, which limit state support for private enterprises on the grounds that it distorts competition - a government may be prohibited from rescuing a failing business and staving off mass redundancies by European Union (EU) treaties or World Trade Organisation rules that are enshrined in its own national laws (Moraitis 2019). In this way, society's tendency to shrink from the unrelenting discipline of capitalist competition can be comprehensively neutered.

Yet according to a second strand of liberal thought, the neo/ordoliberal tradition is politically naive, as it is unable to deal with the question of legitimacy (Gamble, 1996, p.46; Gray, 2015). Keynesianism expresses an awareness of the spectre of revolt and a political will 
to suspend market norms in order to palliate unrest. We refer here to Keynesianism not as a strict economic doctrine, but following Mann (2018), as a distinctly anxious strand of liberal thought that emerged from the French Revolution. Keynesianism, for Mann (ibid, p.95), understands that the politics of necessity cannot be suppressed through legislation: 'The people must be fed, or they will do what is necessary to feed themselves'. Capitalism generates both misery and historically unprecedented levels of civilisation, yet the former always threatens to spill out of its confines and flood the latter. This requires a pragmatic, discretionary state acting to alleviate the worst destitution so as to avoid 'the destruction of existing economic forms in their entirety' (Keynes, 2013, p.380). The Keynesian impulse is further expressed through global governance initiatives, such as Bretton Woods' attempt to protect national welfare states by restricting mobile capital flows. Yet it also takes the form of national violations of neoliberal global governance codes - for instance, European states' breaking of EU budget rules so as to appease domestic constituencies (Kalan et al, 2018). However, this by no means suggests that Keynesianism is sympathetic to mass politics (Dunn, 2018). Rather, it shares with neo/ordoliberalism a desire for depoliticised economic governance, with the levers of demand management operated by 'an insulated and bureaucratic élite' (Bulpitt, 1986, p.27). This vein of liberalism, then, entrusts to enlightened technocrats the power to resist capitalism's impersonal pressures, at certain crucial moments, in order to stave off popular upheaval.

Both neo/ordoliberalism and Keynesianism express fundamental (if partial) truths about the politics of governing alienation. In attempting to marry an adherence to the autonomous logic of capitalism with the creation of a legitimate political project, state governance necessarily has recourse to strategies of technocratic discipline and palliation. In this sense, Keynesian critiques of the nefarious influence of neoliberal ideas on governments in the postBretton Woods era and neoliberal critiques of the Keynesian roots of budgetary indiscipline are both incomplete. Neither are simply 'dangerous ideas' (Blyth 2013), but rather those tasked with the governance of capitalism tend to arrive at such conclusions as a matter of necessity. The depoliticisation of economic governance grants policy-makers autonomy from popular political pressures by establishing 'automatic rules or pilots' (Bulpitt, 1986, p.28). This allows governments to rationalise the domestic economy in line with world averages, without being impeded by political legitimacy concerns (Burnham, 2001; Krippner, 2011). Yet such strategies cannot banish legitimacy questions: faced with the social unrest generated by the dislocating effects of market competition, policy-makers are often forced to adopt 'the activist, rationalist, crisis-fighting mindset of Keynesianism' (Tooze, 2018). Governments thus seek to 'buy time' 
by employing palliative measures that violate the norms of rules-based governance in order to appease popular forces (Streeck, 2014).

This dual character of the governance of alienation, when it is recognised, is often framed sequentially. Most interpretations of Polanyi's double movement describe a pendular dynamic, whereby periods of disembedded market discipline are followed by periods of reembedding in the name of social cohesion (Dale, 2012). However, strategies of depoliticised discipline and palliation are often implemented concurrently, as ad hoc, contradictory responses to the binding pressures of world value relations and national legitimacy. Such hybrid policymaking can be observed in the actions of one of neoliberalism's latest doyens.

Argentina's Mauricio Macri came to power in 2015 following the crisis of Argentina's model of 'export-oriented populism' (Richardson, 2009), which had seen the governments of Nestor Kirchner and Cristina Fernández de Kirchner use the dollar revenues from soybean exports during the 2000 s commodity boom to fund a new 'social contract', including significant welfare provisions and state subsidies (Giraudo; 2019; Wylde, 2016; Murillo, 2015). These dollar revenues had balanced the fact that Argentina had been effectively frozen out of global credit markets since 2001. However, as the commodity boom's end spelled the decreasing viability of this export-led strategy, Macri won the Presidency on a platform of delivering Argentina's reinsertion into the world economy on competitive footing (Macri, 2016). His government sought to depoliticise the state apparatus, re-staffing economic ministries with 'well-regarded technocrats' (The Economist, 2015). This would allow Macri to introduce a battery of reforms aiming to grant Argentina access to credit markets, lower the fiscal deficit, and ultimately raise national competitiveness. Outstanding debt obligations were settled, exchange controls abolished, import restrictions liberalised, interest rates raised, state subsidies slashed, and public sector redundancies announced; with further plans to liberalise labour markets and improve infrastructure (CSIS, 2019).

Yet wary that too much economic pain would compromise his legitimacy and usher Kirchner back to power, Macri protected Kirchner-era welfare programmes - paid for through massive borrowing on global markets (Kerner, 2018). This gradualist approach failed. The peso's value collapsed in spring and summer 2018, as world market sentiment soured in the face of Macri's slow progress, forcing Argentina to negotiate an IMF loan (Mander, 2018). However, even under the political cover of IMF conditionalities, Macri was unable to implement a sudden austerity shock because of growing popular mobilisation against his reforms. In what The Economist (2019) termed his 'last throw of the dice', Macri resorted to price controls on 'essential' products to ease the population's misery. However, this could not 
prevent his poor performance in the August 2019 primary elections, after which his government unveiled another raft of social relief measures that provoked a further fall in the peso's price, eventually leading to his ouster in the October general election (Mander and Smith, 2019; Mander and Stott, 2019). The Macri government, then, trapped between the twin pressures of the world market and national civil society, was forced to desperately operate the levers of both depoliticised discipline and palliation. Rather than signalling the exceptional nature of Argentina's political economy, we argue that this case is an extreme illustration of a fundamental antinomy at the heart of the politics of governing alienation.

This 'moving contradiction', we contend, is not well captured by the concept of the mutual constitution of states and markets nor by the notion of embeddedness (Marx, 1993, p.706). While markets can only exist within an institutional, legal, and cultural framework that is policed by states, the motion of markets cannot be reduced to this framework. Instead, following Marx's account of alienation, the organisation of society along capitalistic lines creates an autonomous market logic that, while remaining wholly dependent for its functioning on the institutional arrangements of bourgeois society, nonetheless dominates that society. States' efforts at governing this system should be understood as the governance of alienation, that is, the challenge of both ensuring the domestic economy's viability within a context of unending global competition over labour productivity and meeting the citizenry's demands regardless of market conditions, all under the banner of a single national project.

\section{Conclusion}

Following the globalisation debate, IPE has come to challenge the dichotomous view of states and markets as engaged in a zero-sum struggle. Often aided by the Polanyian concept of embeddedness, a growing consensus has emerged around the mutual constitution of states and markets, whereby capitalism's evolution is understood as the outcome of 'contingent and deeply political processes of market-making and re-regulation' (Clift, 2014, p.326). The different IPE strands examined here - CPE, constructivist, and neo-Polanyian - represent different articulations of the idea of a co-constitutive relation between states and markets. Yet acknowledging the complementarity of states and markets should not constitute IPE's 'final say' on the matter. In fact, the market's dependence on specific political practices and social norms is a central preoccupation, not only of Polanyian IPE, but of liberal theorists from Smith to Hayek. The 'political embeddedness' of markets thus risks becoming a 'commonplace' 
notion if not situated within the context of capitalism's historically novel alienated logic (Dale, 2011, p.331). If acknowledging the mutual constitution of states and markets constitutes the first step of any serious IPE analysis, the second must be to examine the dynamics that their coconstitution unleashes.

To elucidate these dynamics, we advanced a 'value-form' reading of Marx's concept of alienation, which understands the capitalist economy as the product of definite social practices that nevertheless lock social actors into a compelling developmental logic. In the capitalist market, money-mediated exchange commensurates different goods according to a universal yardstick: the mean labour time socially required for their production. Market exchange generates 'a competitive scramble to meet or exceed average levels of productivity' established internationally as firms are compelled to stay in line with world market prices (McNally, 1993, p.179). This process of competitive commensuration can only occur through the state's sanctioning of a domestically unique and internationally convertible currency that links domestic industry to foreign competition. Inadvertently, states themselves become subject to impersonal competitive forces, as nationally produced wealth is evaluated in relation to the productivity standards of the world market. States become the architects of their own alienation as their market-making power creates abstract competitive dictates that they must struggle to comply with.

This has profound implications for the conceptualisation of state governance of capitalism, which is not adequately captured by the mutual constitution literature. What this article has termed the politics of governing alienation entails a peculiar dilemma whereby states must synchronise the domestic economy with the pace of the world market while ensuring the governability of the domestic social order. This anxiety is at the heart of liberal governance and is expressed by the neo/ordoliberal and Keynesian traditions, with the former articulating the market's need for a 'strong state' to insulate the workings of the economy from excess democracy and the latter stressing the necessity of technocratic palliation to defer the political ramifications of pauperisation. Both strands of liberalism articulate correctly, but one-sidedly, the tensions encountered by political elites when formulating a single national project that abides by global productivity averages and the needs of civil society.

In an attempt to overcome the limitations of the state retreat thesis, the mutual constitution literature rightly sheds light on the state's market-making powers. It misses, however, the fundamentally abstract and impersonal form of power that characterises the global economy, which lies neither within the market's nor the state's hands, but is ultimately exercised upon both market agents and policy-makers by the socially established productivity 
standards of the world market. Although global competition is sustained through the actions of states, it simultaneously constitutes an alienated, externally-imposed imperative, as the antagonistic conditions of the global market compel national economies to produce 'within time' to secure their own survival.

\section{References}

Abdelal, R. (2009). Constructivism as an approach to international political economy. In Blyth, M. (Ed), Routledge Handbook of International Political Economy (pp. 66-72). London: Routledge.

Abdelal, R., Blyth, M. and Parsons, C. (2010). Introduction: Constructing the international economy. In Abdelal, R., Blyth, M., and Parsons, C. (Eds.), Constructing the International Economy (pp. 1-20). Ithaca: Cornell University Press.

Alami, I. (2018). On the terrorism of money and national policy-making in emerging capitalist economies. Geoforum, 96, 21-31.

Althusser, L. (2005) For Marx. London: Verso.

Amable, B. (2003). The Diversity of Modern Capitalism. Oxford: Oxford University Press.

Amable, B. (2017). Structural Crisis and Institutional Change in Modern Capitalism: French Capitalism in Transition. Oxford: Oxford University Press.

Amoore, L. (2002). Globalisation Contested: An International Political Economy of Work. Manchester: Manchester University Press.

Bakker, I. and Silvey, R. (2008). Beyond States and Markets: The Challenges of Social Reproduction. London: Routledge.

Barber, B. (1995). All economies are 'embedded': The career of a concept and beyond. Social Research, 62(2), 387-413.

Barker, C. (2006). Beyond Trotsky: Extending combined and uneven development. In Dunn, B. and Radice, H. (Eds.), 100 Years of Permanent Revolution: Results and Prospects (pp. 72-87). London: Pluto.

Beggs, M. (2017). The state as a creature of money. New Political Economy, 22(5), 463-477.

Berry, C. (2011). Globalisation and Ideology in Britain: Neoliberalism, Free Trade and the Global Economy. Manchester: Manchester University Press.

Block, F. (2001). Introduction. In Polanyi, K., The Great Transformation. Boston: Beacon Press.

Block, F. (2003). Karl Polanyi and the writing of the Great Transformation. Theory and society, 32(3), 275-306. 
Block, F. (2007). Understanding the diverging trajectories of the United States and Western Europe: A neo-Polanyian analysis. Politics \& Society, 35(1), 3-33.

Block, F. and Evans, P. (2005). The state and the economy. In Smelser, N. and Swedberg, R. (Eds.), Handbook of Economic Sociology (pp. 505-526). Princeton: Princeton University Press.

Block, F. and Somers, M. (1984). Beyond the Economistic Fallay: The Holistic Social Science of Karl Polanyi. In Skocpol, T. (Ed.), Vision and Method in Historical Sociology (pp. 4784). Cambridge: Cambridge University Press.

Block, F. and Somers, M. (2004). The Power of Market Fundamentalism: Karl Polanyi's Critique. Cambridge, MA: Harvard University Press.

Blyth, M. (2001). The transformation of the Swedish model: Economic ideas, distributional conflict, and institutional change. World Politics, 54(1), 1-26.

Blyth, M. (2002). Great Transformations: Economic Ideas and Institutional Change in the Twentieth Century. Cambridge: Cambridge University Press.

Blyth, M. (2013). Austerity: The History of a Dangerous Idea. Oxford: Oxford University Press. Bonefeld, W. (2000). The spectre of globalisation: On the form and content of the world market. In Bonefeld, W. and Psychopedis, K. (Eds.), The Politics of Change: Globalization, Ideology and Critique (pp. 31-68). Basingstoke: Palgrave.

Bonefeld, W. (2014). Critical Theory and the Critique of Political Economy. London: Bloomsbury.

Bonefeld, W. (2016). The Strong State and the Free Economy. London: Rowman and Littlefield. Brittan, S. (1971). Steering the Economy: The Role of the Treasury. London: Penguin.

Broome, A. (2014). Issues and Actors in the Global Political Economy. Basingstoke: Palgrave Macmillan.

Bruff, I. (2005). Making sense of the globalisation debate when engaging in political economy analysis. British Journal of Politics and International Relations, 7(2), 261-280.

Bruff, I. (2011). Overcoming the state/market dichotomy. In Shields, S., Macartney, H., and Bruff, I. (Eds.), Critical International Political Economy: Dialogue, Debate and Dissensus (pp. 80-98). Basingstoke: Palgrave Macmillan.

Brunhoff, S. de (1978). The State, Capital and Economic Policy. London: Pluto Press.

Brunhoff, S. de (2003). Value, finance and social classes. In Westra, R. and Zuege, A. (Eds.), Value and the World Economy Today (pp. 40-56). Basingstoke: Palgrave Macmillan.

Bulpitt, J. (1986). The discipline of the new democracy: Mrs Thatcher's domestic statecraft. Political Studies, 34(1), 19-39. 
Burnham, P. (2001). New Labour and the politics of depoliticization. British Journal of Politics and International Relations, 3(2), 127-49.

Burnham, P. (2011). Depoliticising monetary policy: The Minimum Lending Rate experiment in the 1970s. New Political Economy, 16(4), 463-480.

Cahill, D. (2014). The End of Laissez-faire? On the Durability of Embedded Neoliberalism. Cheltenham: Edward Elgar.

Cahill, D. (2018). Polanyi, Hayek and embedded neoliberalism. Globalizations, 15(7), 977-994.

Cairncross, A. (1995). The British Economy Since 1945. Oxford: Blackwell.

Cameron, A. and Palan, R. (2004). The Imagined Economies of Globalization. London: Sage.

Campbell, J. (2004). Institutional Change and Globalization. Princeton: Princeton University Press.

Cangiani, M. (2011). Karl Polanyi’s Institutional Theory: Market Society and its "Disembedded" Economy. Journal of Economic Issues, 45(1), 177-198.

Cangiani, M. (2017). "Social Freedom" in the Twenty-First Century: Rereading Polanyi. Journal of Economic Issues, 51(4), 915-938.

Cerny, P. (1997). Paradoxes of the competition state: The dynamics of political globalization. Government and Opposition, 32(2), 251-274.

Cerny, P. (2010). The competition state today: From raison d'État to raison du Monde. Policy Studies, 31(1), 5-21.

Cerny, P., Menz, G., and Soederberg, S. (2005). Different roads to globalization: Neoliberalism, the competition state, and politics in a more open world. In Soederberg, S., Menz, G., and Cerny, P. (Eds.), Internalizing Globalization: The Rise of Neoliberalism and the Decline of National Varieties of Capitalism (pp. 1-30). Basingstoke: Palgrave Macmillan.

Clapham, J. (1966). The Bank of England: A History, Volume 1. Cambridge: Cambridge University Press.

Clarke, S. (1988). Keynesianism, Monetarism and the Crisis of the State. Aldershot: Edward Elgar.

Clarke, S. (1991). Marx, Marginalism, and Modern Sociology: From Adam Smith to Max Weber. Basingstoke: Macmillan.

Clift, B. (2014). Comparative Political Economy: States, Markets and Global Capitalism. Basingstoke: Palgrave Macmillan.

Clift, B. (2017). French economic policy: Theory development and the three 'I's. In Elgie, R., Grossman, E., and Mazur, A. G. (Eds.), The Oxford Handbook of French Politics (pp. 509-534). Oxford: Oxford University Press. 
Clift, B. and Woll, C. (2012). Economic patriotism: Reinventing control over open markets. Journal of European Public Policy, 19(3), 307-323.

Cohen, B. (1977). Organizing the World's Money. Basingstoke: Macmillan.

Cohen, B. (2007). The Transatlantic divide: Why are American and British IPE so different?. Review of International Political Economy, 14(2), 197-219.

Cohen, B. (2008). International Political Economy: An Intellectual History. Princeton: Princeton University Press.

Cohen, B. (2015). Currency Power: Understanding Monetary Rivalry. Princeton: Princeton University Press.

Crouch, C. and Streeck, W. (1997) Political Economy of Modern Capitalism: Mapping Convergence and Diversity. London: Sage.

CSIS (2019). The Macri government's reform program: A scorecard. Center for Strategic and International Studies.

Dale, G. (2010). Karl Polanyi: The Limits of the Market. Cambridge, MA: Polity Press.

Dale, G. (2011). Lineages of embeddedness: On the antecedents and successors of a Polanyian concept. American Journal of Economics and Sociology, 70(2), 306-339.

Dale, G. (2012). Double Movements and pendular forces: Polanyian Perspectives on the Neoliberal Age. Current Sociology, 60(1), 3-27.

Dale, G. (2016). Reconstructing Karl Polanyi: Excavation and Critique. London: Pluto Press.

Dasgupta, S. \& Singh, A. (2006). Manufacturing, Services and Premature Deindustrialization in Developing Countries: A Kaldorian Analysis. Research Paper 2006/049. Helsinki: UNUWIDER.

Davies, G. (2002) A History of Money: From Ancient Times to the Present Day. Cardiff: University of Wales Press.

Dunn, B. (2018). On the prospects of a return to Keynes: Taking Keynes's political philosophy seriously. Global Society, 32(3), 302-323.

Eichengreen, B. (1994). The Bretton Woods System: Paradise Lost. Centre for International and Development Economics Research, Working Paper C94-043. Berkley: University of California.

Eichengreen, B. (2011). Exorbitant Privilege: The Rise and Fall of the Dollar and the Future of the International Monetary System. Oxford: Oxford University Press.

Elias, J. and Roberts, A. (2018). Handbook on the International Political Economy of Gender. Cheltenham: Edward Elgar. 
Feld, L., Köhler, E., and Nientiedt, D. (2015). Ordoliberalism, pragmatism and the eurozone crisis: How the German tradition shaped economic policy in Europe. Freiburger Diskussionspapiere zur Ordnungsökonomik No. 15/04. Freiburg: Albert-LudwigsUniversität Freiburg.

Fromm, E. (2013). Marx's Concept of Man. London: Bloomsbury.

Gamble, A. (1996). Hayek and the left. Political Quarterly, 67(1), 46-53.

Gemici, K. (2008). Karl Polanyi and the antinomies of embeddedness. Socio-Economic Review, 6(1), 5-33.

Geske, M. (2000). Globalisation is what States Make of it: Constructivism, US Foregin Economic Policy and the Peso Crisis. International Policy, 37(3), 301-322

Giraudo, M. E. (2019). Dependent development in South America: China and the soybean nexus. Journal of Agrarian Change. doi: 10.1111/joac.12333.

Goodwin, G. (2018). Rethinking the Double Movement: Expanding the Frontiers of Polanyian Analysis in the Global South. Development and Change, 49(5), 1268-1290.

Gray, J. (2015). 30 July. The Friedrich Hayek I knew, and what he got right - and wrong. New Statesman.

Hall, P. (2007). The evolution of varieties of capitalism in Europe. In Hancké, B., Rhodes, M., and Thatcher, M. (Eds.), Beyond Varieties of Capitalism: Conflict, Contradictions, and Complementarities in the European Economy (pp. 39-85). Oxford: Oxford University Press.

Hall, P. A. and Thelen, K. (2009). Institutional change in varieties of capitalism. Socio-Economic Review, 7(1), 7-34.

Hall, P.A. and Soskice, D. (2001). Varieties of capitalism: The Institutional Foundations of Comparative Advantage. Oxford: Oxford University Press.

Hancké, B., Rhodes, M. and Thatcher, M. (2007). Introduction: Beyond Varieties of Capitalism. In Hancké, B., Rhodes, M., and Thatcher, M. (Eds.), Beyond Varieties of Capitalism: Conflict, Contradictions, and Complementarities in the European Economy (pp. 39-85). Oxford: Oxford University Press.

Hancké, B. (2009). Debating Varieties of Capitalism: A Reader. Oxford: Oxford University Press.

Hay, C. and Rosamond, B. (2002). Globalization, European integration and the discursive construction of economic imperatives. Journal of European public policy, 9(2), 147-167. 
Hay, C. (2002). Globalisation as a problem of political analysis: Restoring agents to a "process without a subject" and politics to a logic of economic compulsion. Cambridge Review of International Affairs, 15(3), 379-392.

Hayek, F. A. (1982). Law, Legislation and Liberty: A New Statement of the Liberal Principles of Justice and Political Economy. London: Routledge.

Heinrich, M. (2012). An Introduction to the Three Volumes of Karl Marx's Capital. New York: Monthly Review Press.

Heinrich, M. (2016). "Capital” after MEGA: Discontinuities, interruptions, and new beginnings. Crisis and Critique, 3(3), 92-138.

Held, D. (1995). Democracy and the Global Order: From the Modern State to Cosmopolitan Governance. Cambridge: Polity Press.

Helleiner, E. (2003). The Making of National Money: Territorial Currencies in Historical Perspective. Ithaca: Cornell University Press.

Hirsch, J. (1997). Globalization of capital, nation-states and democracy. Studies in Political Economy, 54(1), 39-58.

Hollingsworth, J. R. and Boyer, R. (1997). Contemporary Capitalism: The Embeddedness of Institutions. Cambridge: Cambridge University Press.

Hopkins, K. (1980). Taxes and trade in the Roman Empire (200 B.C.-A.D. 400). Journal of Roman Studies, 70, 101-125.

Jackson, G., and Deeg, R. (2008). From comparing capitalisms to the politics of institutional change. Review of International Political Economy, 15(4), 680-709.

Jessop, B. (2003). The Future of the Capitalist State. Oxford: Polity.

Kalan, F. D., Popescu, A., and Reynaud, J. (2018). 'Thou shalt not breach: The impact on sovereign spreads of non-complying with the EU fiscal rules', IMF Working Paper (Washington, D.C.: IMF).

Kerner, D. (2018) 1 October. Mauricio Macri's failure to plan has put Argentina in a tight spot. Financial Times.

Kettell, S. (2004). The Political Economy of Exchange Rate Policy-Making: From the Gold Standard to the Euro. Basingstoke: Palgrave Macmillan.

Keynes, J. M. (2013). The General Theory of Employment, Interest and Money. Cambridge: Cambridge University Press.

Knafo, S. (2020). Rethinking Neoliberalism After the Polanyian Turn. Review of Social Economy. DOI: 10.1080/00346764.2020.1733644

Knapp, A. and Wright, V. (2006). The Government and Politics of France. London: Routledge. 
Knapp, G. F. (1924). The State Theory of Money. London: Macmillan.

Krippner, G. (2001). The elusive market: Embeddedness and the paradigm of economic sociology. Theory and Society, 30(6), 775-810.

Krippner, G. (2007). The making of US monetary policy: Central bank transparency and the neoliberal dilemma. Theory and Society, 36(6), 477-513.

Krippner, G. (2011). Capitalizing on Crisis: The Political Origins of the Rise of Finance. Cambridge: Harvard University Press.

Krippner, G. and Alvarez, A. S. (2007). Embeddedness and the intellectual projects of economic sociology. Annual Review of Sociology, 33, 219-240.

Lerner, A. P. (1947). Money as a creature of the state. American Economic Review, 37(2), 312317.

Levy, J. (2006). The state also rises: The roots of contemporary state activism. In Levy, J. (Ed), The State after Statism (pp. 1-28). Cambridge, MA: Harvard University Press.

Levy, J. (2008). From the dirigiste state to the social anaesthesia state: French economic policy in the longue durée. Modern and Contemporary France, 16(4), 417-435.

Levy, J., Miura, M., and Park, G. (2006). Exiting etatisme? New directions in state policy in France and Japan. In Levy, J. (Ed), The State after Statism (pp. 93-136). Cambridge, MA: Harvard University Press.

Lister, M. and Marsh, D. (2006). Conclusion. In Hay, C., Lister, M. and Marsh, D. The State: Theories and Issues. Basingstoke: Palgrave Macmillan.

Lotz, C. (2014). The Capitalist Schema: Time, Money, and the Culture of Abstraction. Laham: Lexington Books.

Machado, N. M. C. (2011). Karl Polanyi and the New Economic Sociology: Notes on the concept of (dis)embeddedness. RCCS Annual Review, 3, 1-22.

Macri, M. (2016). 1 March. Palabras del presidente Mauricio Macri en la $134^{\circ}$ apertura de sesiones ordinarias del Congreso. Casa Rosada.

Mander, B. (2018). 18 May. 'Why Argentina has returned to the IMF - in charts. Financial Times.

Mander, B. and Smith, C. (2019). 14 August. Argentina's peso falls again as Macri tries to shore up support. Financial Times.

Mander, B. and Stott, M. (2019). 28 October. Argentina's Peronists return to power as Macri concedes defeat. Financial Times.

Mann, G. (2018). In the Long Run We're All Dead: Keynesianism, Political Economy, and Revolution. London: Verso.

Marx, K. (1976). Capital, Volume I. London: Penguin Books. 
Marx, K. (1992) Early Writings (London: Penguin Books).

Marx, K. (1993). Grundrisse. London: Penguin.

Marx, K. (2010). Economic manuscripts of 1861-1863. In Marx \& Engels Collected Works, Volume 33 (pp. 9-426). London: Lawrence and Wishart.

McNally, D. (1993). Against the Market: Political Economy, Market Socialism and the Marxist Critique. London: Verso.

McNally, D. (2014). The blood of the commonwealth: War, the state, and the making of world money. Historical Materialism, 22(2), 3-32.

Mészáros, I. (1970). Marx’s Theory of Alienation. New York: Merlin Press.

Mittelman, J. H. (2000). The Globalization Syndrome: Transformation and Resistance. Princeton: Princeton University Press.

Molina, O. and Rhodes, M. (2007). The political economy of adjustment in mixed market economies: A study of Spain and Italy. In Hancké, B., Rhodes, M., and Thatcher, M. (Eds.), Beyond Varieties of Capitalism: Conflict, Contradictions, and Complementarities in the European Economy (pp. 223-252). Oxford: Oxford University Press.

Moraitis, A.B. (2019) Transnational Depoliticisation and Industrial Policy: The European Commission and French Steel (1980-1984). New Political Economy. DOI: $10.1080 / 13563467.2019 .1613352$

Murillo, V. M. (2015). Curtains for Argentina's Kirchner era. Current History, 114(769), 56-61.

Musto, M. (2010) 'Revisiting Marx's Concept of Alienation', Socialism and Democracy, 24(3): 79-101.

Ollman, B. (1971). Alienation: Marx's Conception of Man in Capitalist Society. London: Cambridge University Press.

Peck, J. (2010). Constructions of Neoliberal Reason. Oxford: Oxford University Press.

Peck, J. and Theodore, N. (2007). Variegated capitalism. Progress in Human Geography, 31(6), 731-772.

Pitts, F. H. (2019). Value form theory, Open Marxism, and the New Reading of Marx. In Dinerstein, A. C. , Vela, A. G., Gonzalez, E., and Holloway, J. (Eds.), Open Marxism IV: Against a Closing World. London: Pluto.

Polanyi, K. (1957). The economy as instituted process. In Polanyi, K., Arensberg, C. M. and Pearson, H. W. (eds.) Trade and Market in the Early Empires: Economies in History and Theory, Glencoe: The Free Press.

Polanyi, K. (2001). The Great Transformation: The Political and Economic Origins of Our Time.

Boston: Beacon Press. 
Postone, M. (2003). Time, Labor, and Social Domination: A Reinterpretation of Marx's Critical Theory. Cambridge: Cambridge University Press.

Ravenhill, J. (2017). Global Political Economy, Fifth Edition. Oxford: Oxford University Press.

Richardson, N. (2009). Export-oriented populism: Commodities and coalitions in Argentina. Studies in Comparative International Development, 44(3), 228-255.

Rodrik, D. (2015). Work and Human Development In a Deindustrializing World. United Nations Human Development Report Office. New York: United Nations.

Rodrik, D. (2016). Premature deindustrialization. Journal of Economic Growth, 21(1), 1-33.

Rowthorn, R. E. and Wells, J. R. (1987). De-Industrialization and Foreign Trade. Cambridge: Cambridge University Press.

Rubin, I. I. (1973) Essays on Marx's Theory of Value. Montréal: Black Rose Books.

Ruggie, J. (1982). International regimes, transactions, and change: Embedded liberalism in the postwar economic order. International Organization, 36(2), 379-415.

Saad-Filho, A. (2019). Value and Crisis: Essays on Labour, Money and Contemporary Capitalism. Boston: Brill.

Schmidt, V. (2009). Putting the political back into political economy by bringing the state back in yet again. World Politics, 61(3), 516-546.

Slobodian, Q. (2018) Globalists: The End of Empire and the Birth of Neoliberalism. London: Harvard University Press.

Smith, A. (2001). An Inquiry into the Nature and Causes of the Wealth of Nations (London: Electric Book Company).

Smith, M. (1993). Alienation, exploitation, and abstract labour: A humanist defense of Marx's theory of value. Review of Radical Political Economics, 26(1), 110-133.

Smith, N. (2010). Uneven Development: Nature, Capital, and the Production of Space. London: Verso.

Somers, M. R. and Block, F. (2005). From poverty to perversity: Ideas, markets, and institutions over 200 years of welfare debate. American Sociological Review, 70(2), 260-287.

Sørensen, G. (2004). The Transformation of the State: Beyond the Myth of Retreat. Basingstoke: Palgrave Macmillan.

Strange, S. (1996). The Retreat of the State: The Diffusion of Power in the World Economy. Cambridge: Cambridge University Press.

Streeck, W. (2014). Buying Time: The Delayed Crisis of Democratic Capitalism. London: Verso. The Economist (2015). 26 November. The end of populism. The Economist. 
The Economist (2019). 18 April. Mauricio Macri freezes prices - last throw of the dice. The Economist.

Tilley, L. and Shilliam, R. (2018). Raced markets: An introduction. New Political Economy, 23(5), 534-543.

Tomba, M. (2012). Marx's Temporalities. Leiden: Brill.

Tooze, A. (2018). Tempestuous seasons. London Review of Books, 40(17), 19-21.

Underhill, G. (2000). State, market, and global political economy: Genealogy of an (inter-?) discipline. International Affairs, 76(4), 805-824.

Underhill, G. R. and Zhang, X. (2005). The changing state-market condominium in East Asia: Rethinking the political underpinnings of development. New Political Economy, 10(1), $1-24$.

Vail, M. (2018) Liberalism in Illiberal States. Oxford: Oxford University Press.

Vogel, S. K. (2018). Marketcraft: How Governments Make Markets Work. New York: Oxford University Press.

Watson, M. (2005). Foundations of International Political Economy. Basingstoke: Palgrave Macmillan.

Watson, M., and Hay, C. (2003). The discourse of globalisation and the logic of no alternative: Rendering the contingent necessary in the political economy of New Labour. Policy and Politics, 31(3), 289-305.

Wood, E. M. (2002) The Origin of Capitalism: A Longer View (London: Verso).

Wylde, C. (2016). Post-neoliberal developmental regimes in Latin America: Argentina under Cristina Fernandez de Kirchner. New Political Economy, 21(3), 322-341. 